\title{
Reichenbachiella faecimaris sp. nov., isolated from a tidal flat, and emended descriptions of the genus Reichenbachiella and Reichenbachiella agariperforans
}

Correspondence

Dong-Hyun Roh

dhroh@chungbuk.ac.kr

\author{
In-Tae Cha, ${ }^{1}$ Yong-Sik Oh, ${ }^{1}$ Soo-Je Park, ${ }^{1}$ Byoung-Joon Park, ${ }^{1}$ \\ Je-Kwan Lee, ${ }^{1}$ Chae-Sung Lim, ${ }^{1}$ A-Rum Park, ${ }^{1}$ Jae-Soo Yoo, ${ }^{2}$ \\ Dong-Hun Lee, ${ }^{1}$ Sung-Keun Rhee ${ }^{1}$ and Dong-Hyun Roh ${ }^{1}$
}

\author{
${ }^{1}$ Department of Microbiology and Biotechnology Research Institute, Chungbuk National University, \\ Cheongju 361-763, Chungbuk, Republic of Korea \\ ${ }^{2}$ School of Electrical and Computer Engineering, Chungbuk National University, Cheongju 361- \\ 763, Chungbuk, Republic of Korea
}

The genus Reichenbachia and the species Reichenbachia agariperforans (family Cytophagaceae, phylum Bacteroidetes; Euzéby, 1997; Ludwig et al., 2008) were originally proposed by Nedashkovskaya et al. (2003) to accommodate a Gram-staining-negative, strictly aerobic, oxidase-, catalase- and alkaline phosphatase-positive, rod-shaped bacterial strain that was motile by gliding. As the genus name Reichenbachia was illegitimate, it was subsequently changed to Reichenbachiella and new, modified genus and species descriptions were published (Nedashkovskaya et al., 2005). At the time of writing, Reichenbachiella agariperforans remained the only species in the genus. In this study, we report on the polyphasic taxonomic characterization of the

The GenBank/EMBL/DDBJ accession numbers for the 16S rRNA gene sequences of strains $\mathrm{PCP} 11^{\top}$ and PCP104 are GU143096 and GU143095, respectively.
Reichenbachiella-like bacterial strains $\mathrm{PCP} 11^{\mathrm{T}}$ and PCP104, isolated from a tidal flat of the Yellow Sea, Korea. The two strains are proposed to represent a novel species of the genus Reichenbachiella.

During a study of bacterial diversity at a tidal flat of the Yellow Sea in the Muchangpo region of Korea ( $36^{\circ} 14^{\prime} 28^{\prime \prime}$ $\mathrm{N} 126^{\circ} 31^{\prime} 54^{\prime \prime} \mathrm{E}$ ), two novel bacterial strains were isolated. For isolation of bacteria, tidal-flat sediment collected in sterile conical tubes was serially diluted with filter-sterilized $(0.2 \mu \mathrm{m}$ pore size; Millipore) natural seawater containing $0.01 \%$ yeast extract. After incubation at $25{ }^{\circ} \mathrm{C}$ under aerobic conditions for 2 weeks, an aliquot of the last dilution showing turbidity was spread onto artificial seawater (ASW) agar and incubated at $25{ }^{\circ} \mathrm{C}$ for 2 weeks. ASW broth and agar contained $\left(\mathrm{l}^{-1}\right) 1 \mathrm{~g}$ yeast extract, $23.6 \mathrm{~g} \mathrm{NaCl}, 0.64 \mathrm{~g} \mathrm{KCl}$ and $4.53 \mathrm{~g} \mathrm{MgCl}_{2} \cdot 6 \mathrm{H}_{2} \mathrm{O}$, with 
$1.5 \%$ agar for solidification. Single colonies were purified by transfer onto marine agar 2216E (MA; Difco) and incubation at $25{ }^{\circ} \mathrm{C}$ for 3 days. The strains were stored at $-80{ }^{\circ} \mathrm{C}$ in marine broth 2216 (MB; Difco) supplemented with $25 \%(\mathrm{w} / \mathrm{v})$ glycerol.

Genomic DNA of the two isolates was extracted using a commercial genomic DNA extraction kit (Solgent). The $16 \mathrm{~S}$ rRNA gene was amplified from the chromosomal DNA using the universal bacterial primers 27F (5'-AGAGTTTGATCMTGGCTCAG-3'; Escherichia coli positions 827) and 1492R (5'-TACGGYTACCTTGTTACGACTT-3'; 1492-1510) (Park et al., 2006; Weisburg et al., 1991). Purified PCR products were sequenced by Solgent Co. Ltd (Daejeon, Korea) using primers 27F, 338F, 786R and 1492R (Weisburg et al., 1991). Nearly complete $16 \mathrm{~S}$ rRNA gene sequences were compiled using the SeqMan software (DNASTAR) and sequences of related taxa were obtained from the GenBank database. Sequence alignments were performed using the CLUSTAL_X program (Thompson et al., 1997). Gaps were edited in the BioEdit program (Hall, 1999). Nucleotide similarity values were calculated using the EzTaxon program (http://www.eztaxon.org; Chun et al., 2007) and evolutionary distances were calculated using Kimura's two-parameter model (Kimura, 1983). Phylogenetic trees were reconstructed using the neighbourjoining (Saitou \& Nei, 1987) and maximum-parsimony (Fitch, 1971) algorithms by using the MEGA 4 program (Tamura et al., 2007). Bootstrap analysis was performed with 1000 resampled datasets using the built-in programs of MEGA 4.

On the basis of analysis of 16S rRNA gene sequences (1429 bp for both strains), strains PCP $11^{\mathrm{T}}$ and PCP104 were shown to belong to the family Cytophagaceae, phylum Bacteroidetes, and the highest sequence similarity was found with $R$. agariperforans $\mathrm{KMM} 3525^{\mathrm{T}}$ (95.8 and $96.0 \%$, respectively) (Fig. 1). Members of the genera Fulvivirga, Roseivirga, Fabibacter and Marinoscillum were the next closest relatives of the new isolates, with sequence similarities $\leqslant 91 \%$. Strains $\mathrm{PCP} 11^{\mathrm{T}}$ and PCP104 shared $99.4 \%$ sequence similarity; they clearly belonged to the genus Reichenbachiella, as shown by the high bootstrap values (both $100 \%$ ) of the neighbour-joining and maximum-parsimony phylogenetic trees (Fig. 1). Hence, $R$. agariperforans KCTC $12369^{\mathrm{T}}$ was obtained from the Korean Collection for Type Cultures (Daejeon, Republic of Korea) and used as a reference strain in most phenotypic tests.

Strains PCP $11^{\mathrm{T}}$ and PCP104 and R. agariperforans KCTC $12369^{\mathrm{T}}$ were routinely grown on MA at $28{ }^{\circ} \mathrm{C}$ for 3 days. Morphology and size of cells grown under these conditions were observed by phase-contrast microscopy (Nikon 80i) and the production of endospores was examined using cells grown at $28{ }^{\circ} \mathrm{C}$ for 14 days on MA. The presence of gliding motility was assessed by microscopic observation of a hanging drop from a fresh MB culture and of the edge of a young colony on a glass slide coated with MA (Agarwal et al., 1997; Bernardet et al., 2002). Gram staining was performed using the BD Gram stain kit according to the instructions of the manufacturer. Catalase and oxidase activities were assessed by bubble production in $3 \%(\mathrm{v} / \mathrm{v})$ $\mathrm{H}_{2} \mathrm{O}_{2}$ and using the bioMérieux Orientation test kit, respectively. Growth under anaerobic conditions was assessed after 7 days of incubation on MA at $28{ }^{\circ} \mathrm{C}$ in the GasPak EZ anaerobic container system (BD). The production of flexirubin-type pigments was assessed by using the $\mathrm{KOH}$ test (Reichenbach, 1989; Bernardet et al., 2002). Carotenoid pigments were extracted from cell pellets washed with methanol $(4 \mathrm{ml})$ at $4{ }^{\circ} \mathrm{C}$ overnight and the presence of absorption maxima in the UV-visible spectrum at 450 and $480 \mathrm{~nm}$, characteristic of carotenoids in $R$. agariperforans KCTC $12369^{\mathrm{T}}$, was examined.

Growth was assessed at $0,4,10,20,25,30,35$ and $40{ }^{\circ} \mathrm{C}$ after 3 days of incubation in MB. Requirement for and tolerance of $\mathrm{NaCl}$ were evaluated after incubation at $28{ }^{\circ} \mathrm{C}$ for 2 weeks in a liquid medium containing $\left(1^{-1}\right) 1 \mathrm{~g}$ yeast extract, $5 \mathrm{~g} \mathrm{~K}_{2} \mathrm{HPO}_{4}, 0.5 \mathrm{~g} \mathrm{MgSO}_{4} \cdot 7 \mathrm{H}_{2} \mathrm{O}, 0.5 \mathrm{~g} \mathrm{CaCl}$, $0.05 \mathrm{~g} \mathrm{FeSO}_{4} \cdot 7 \mathrm{H}_{2} \mathrm{O}$ and $0.028 \mathrm{~g} \mathrm{NH}_{4} \mathrm{Cl}$ and supplemented with $0-20 \%(\mathrm{w} / \mathrm{v}) \mathrm{NaCl}$ (at intervals of $1 \%)$. Growth at $\mathrm{pH}$ 5.0-9.0 (at intervals of $0.5 \mathrm{pH}$ units) was assessed in $\mathrm{MB}$ at $28{ }^{\circ} \mathrm{C}$ for 3 days. The medium was adjusted to the desired $\mathrm{pH}$ with $1 \mathrm{M} \mathrm{HCl}$ or $\mathrm{NaOH}$. Acid production from various substrates, assimilation of carbon sources and enzyme activities were determined using API 20NE, API ID32GN, API 50CH and API ZYM galleries according to the instructions of the manufacturer (bioMérieux) except that the culture was suspended in $2 \%(\mathrm{w} / \mathrm{v})$ sea salts solution supplemented with $0.01 \%$ yeast extract (González et al., 1997) and that galleries were incubated at $28{ }^{\circ} \mathrm{C}$ for 3 days. R. agariperforans KCTC $12369^{\mathrm{T}}$ was also included in the API tests and all tests were performed under the same conditions. Hydrolysis of starch (soluble or from rice; $1 \%, \mathrm{w} / \mathrm{v})$, agar $(1.5 \%, \mathrm{w} / \mathrm{v})$, alginate $(1 \%, \mathrm{w} / \mathrm{v})$, gelatin $(1 \%, w / v)$, urea $(1 \%, w / v)$, CM-cellulose $(1 \%$, w/v), filter paper, chitin $(1 \%, \mathrm{w} / \mathrm{v})$, casein $(1 \%, \mathrm{w} / \mathrm{v})$ and Tweens 20 , 40, 60 and $80(1 \%, \mathrm{v} / \mathrm{v})$ was tested on ASW agar (Smibert \& Krieg, 1994). DNA hydrolysis was assessed on DNase test agar with methyl green (Difco) supplemented with $3 \%$ $\mathrm{NaCl}$ (final concentration). The production of $\mathrm{H}_{2} \mathrm{~S}$ was tested on peptone iron agar (Difco) supplemented with $3 \% \mathrm{NaCl}$ (final concentration). The following antibiotics were tested on MA at $28{ }^{\circ} \mathrm{C}$ for 7 days using the discdiffusion method with laboratory-prepared discs containing the indicated amounts ( $\mu \mathrm{g}$ per disc): ampicillin (10), chloramphenicol (25), erythromycin (15), gentamicin (10), kanamycin (30), mitomycin C (50), penicillin G (10), streptomycin (10) and tetracycline (30).

The phenotypic characteristics of strains $\mathrm{PCP} 11^{\mathrm{T}}$ and PCP104 are given in the species description and are compared with those of R. agariperforans KCTC $12369^{\mathrm{T}}$ in Table 1.

For cellular fatty acid analysis, strains $\mathrm{PCP} 11^{\mathrm{T}}$ and PCP104 and R. agariperforans KCTC $12369^{\mathrm{T}}$ were cultivated on MA 


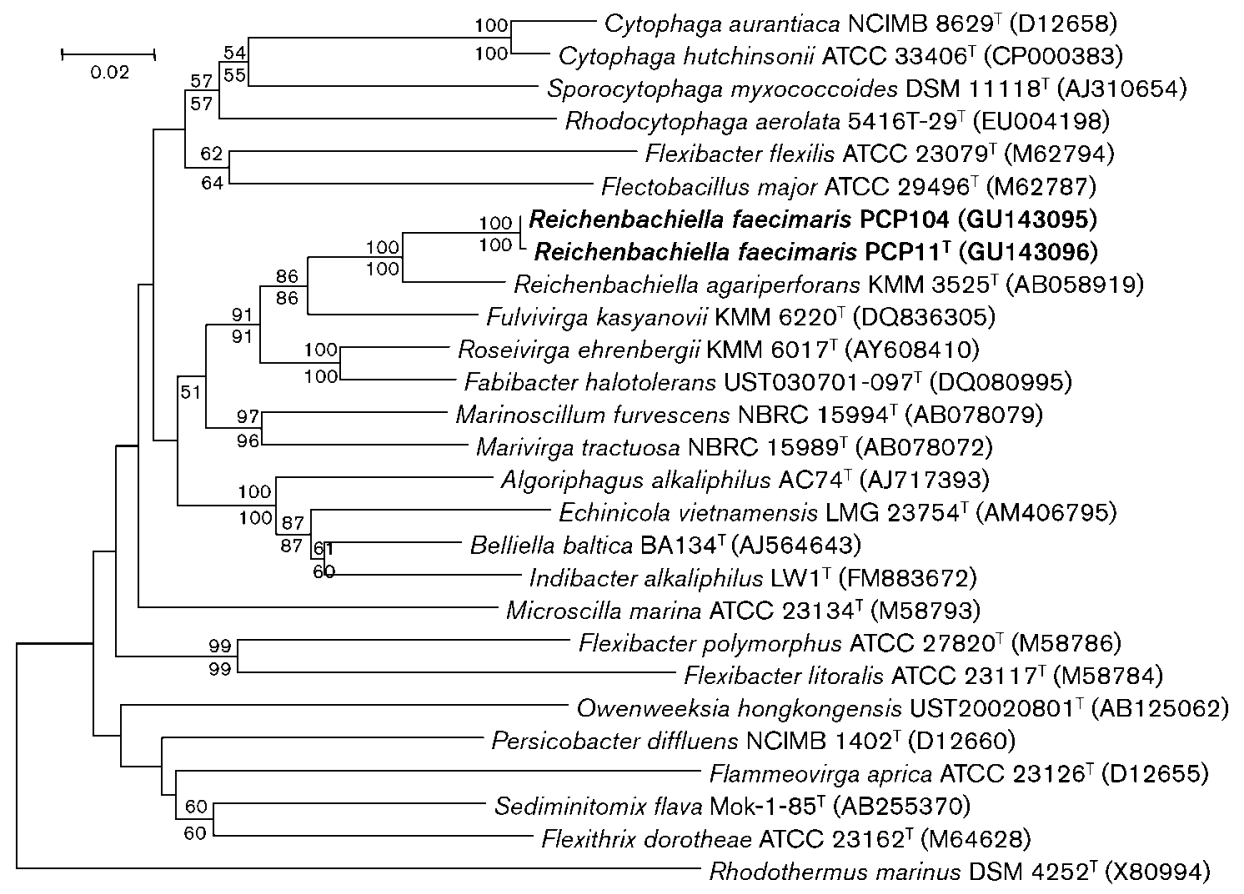

Fig. 1. Phylogenetic tree based on $16 \mathrm{~S}$ rRNA gene sequences showing the positions of strains $\mathrm{PCP} 11^{\top}$ and $\mathrm{PCP} 104, R$. agariperforans KMM $3525^{\top}$ and representatives of the family Cytophagaceae. The sequence of Rhodothermus marinus DSM $4252^{\top}$ was used as an outgroup and GenBank accession numbers are given in parentheses. Bootstrap percentages (based on 1000 replications) $>50 \%$ are shown at branching points (neighbour-joining, above line; maximum-parsimony, below line). Bar, 0.02 substitutions per nucleotide position.

( $\mathrm{pH}$ 7.5) for 3 days at $28{ }^{\circ} \mathrm{C}$. Cellular fatty acids were saponified, methylated, extracted and analysed (Sasser, 1990) according to the protocol of the Sherlock Microbial Identification System (MIDI) by using the TSBA 40 method. Extracts were analysed by GC (Hewlett Packard 6890) and identified by comparing the fatty acid profiles to the TSBA 40 database provided with the Sherlock software 2.95. Isoprenoid quinones were extracted with chloroform/ methanol $(2: 1, \mathrm{v} / \mathrm{v})$, evaporated under vacuum and reextracted in $\mathrm{n}$-hexane-water $(1: 1, \mathrm{v} / \mathrm{v})$. The crude menaquinones in $\mathrm{n}$-hexane were then purified using Sep-Pak Vac Cartridges Silica (Waters) and subsequently analysed by HPLC, as described previously (Hiraishi et al., 1996).

The major cellular fatty acids of strains $\mathrm{PCP} 11^{\mathrm{T}}$ and PCP104 were iso- $\mathrm{C}_{15: 0}$ (21.9 and $20.6 \%$, respectively), summed feature $4\left(\mathrm{C}_{16: 1} \omega 7 c\right.$ and/or iso- $\mathrm{C}_{15: 0} 2-\mathrm{OH} ; 17.3$ and $\left.14.3 \%\right)$ and $\mathrm{C}_{15: 0}$ (11.4 and 5.0\%) (Table 2). The two isolates shared very similar fatty acid compositions but they differed from $R$. agariperforans KCTC $12369^{\mathrm{T}}$ in the proportions of several fatty acids, especially $\mathrm{C}_{16: 1} \omega 5 c, \mathrm{C}_{15: 0}$, iso- $\mathrm{C}_{15: 1} \mathrm{~F}$ and iso$\mathrm{C}_{16: 0}$. Menaquinone 7 (MK-7) was the major respiratory quinone of strains $\mathrm{PCP} 11^{\mathrm{T}}$ and PCP104, in line with all members of the family Cytophagaceae.

Chromosomal DNA extracted for 16S rRNA gene amplification was also used for determination of the $\mathrm{G}+\mathrm{C}$ content. RNA in the DNA solution was removed by incubation with a mixture of RNase A and T1 (each $20 \mathrm{U}$ $\mathrm{ml}^{-1}$ ) at $30{ }^{\circ} \mathrm{C}$ for $1 \mathrm{~h}$. The $\mathrm{G}+\mathrm{C}$ content was analysed as described by Mesbah et al. (1989) using reversed-phase HPLC. The DNA G $+\mathrm{C}$ contents of strains PCP $11^{\mathrm{T}}$ and PCP104 were 39.6 and $41.9 \mathrm{~mol} \%$, respectively. These values were significantly lower than that reported for R. agariperforans KMM $3525^{\mathrm{T}}$ (44.5 mol\%; Nedashkovskaya et al., 2003).

Because of the rather low level of 16S RNA gene sequence similarity between strains $\mathrm{PCP} 11^{\mathrm{T}}$ and PCP104 and $R$. agariperforans KCTC $12369^{\mathrm{T}}$, we did not perform DNADNA hybridization experiments.

On the basis of phenotypic characteristics and phylogenetic inference, strains PCP $11^{\mathrm{T}}$ and PCP104 should be placed in the genus Reichenbachiella within a novel species, for which the name Reichenbachiella faecimaris sp. nov. is proposed. On the basis of the data obtained in this study, emended descriptions of the genus Reichenbachiella and Reichenbachiella agariperforans are also proposed.

\section{Emended description of the genus Reichenbachiella Nedashkovskaya et al. 2005}

The description of the genus Reichenbachiella is as given by Nedashkovskaya et al. (2005) with the following modifications and additions. Members of some species produce carotenoid and flexirubin-type pigments. The predominant fatty acids are iso- $\mathrm{C}_{15: 0}$ and summed feature $4\left(\mathrm{C}_{16: 1} \omega 7 c\right.$ 
Table 1. Differential characteristics of strains $\mathrm{PCP} 11^{\top}$ and $\mathrm{PCP} 104$ and $R$. agariperforans KCTC $12369^{\top}$

Strains: 1, strain PCP11 ${ }^{\mathrm{T}}$; 2, strain PCP104; 3, R. agariperforans KCTC $12369^{\mathrm{T}}$. All data are from this study unless indicated. All strains are strictly aerobic, Gram-staining-negative rods, motile by gliding and oxidase- and catalasepositive. + , Positive; -, negative; $\mathrm{w}$, weakly positive.

\begin{tabular}{|c|c|c|c|}
\hline Characteristic & 1 & 2 & 3 \\
\hline Colony pigmentation & Beige & Beige & Orange \\
\hline Colonies sunken into the agar & - & - & + \\
\hline \multicolumn{4}{|l|}{ Production of: } \\
\hline Flexirubin pigments & - & - & + \\
\hline Carotenoid pigments & - & - & + \\
\hline \multicolumn{4}{|l|}{ Ranges for growth } \\
\hline $\mathrm{NaCl}$ concentration $(\mathrm{w} / \mathrm{v}, \%)$ & $1-5$ & $1-5$ & $1-6^{*}$ \\
\hline Temperature $\left({ }^{\circ} \mathrm{C}\right)$ & $5-35$ & $5-35$ & $4-35^{*}$ \\
\hline $\mathrm{pH}$ & $5.5-8.5$ & $5.5-8.5$ & $5.5-10.0^{*}$ \\
\hline \multicolumn{4}{|l|}{ Hydrolysis of: } \\
\hline Agar & - & - & + \\
\hline Gelatin & - & - & $+^{*}$ \\
\hline Casein & + & + & - \\
\hline Alginate & - & - & + \\
\hline Tween 20 & - & - & + \\
\hline DNA & - & - & + \\
\hline \multicolumn{4}{|l|}{ Production of acid from: } \\
\hline D-Xylose & - & - & + \\
\hline D-Galactose & + & + & - \\
\hline Maltose & + & + & $\mathrm{w}$ \\
\hline Sucrose & + & - & w \\
\hline Trehalose & + & + & - \\
\hline Inulin & + & - & - \\
\hline Gentiobiose & + & + & - \\
\hline L-Fucose & - & - & + \\
\hline \multicolumn{4}{|l|}{ Assimilation of: } \\
\hline D-Mannose & - & - & + \\
\hline D-Ribose & $\mathrm{w}$ & $\mathrm{W}$ & - \\
\hline Glycogen & + & + & - \\
\hline Phenylacetate & + & + & - \\
\hline Lactate & $\mathrm{w}$ & $\mathrm{w}$ & - \\
\hline L-Proline & + & + & - \\
\hline \multicolumn{4}{|l|}{ Enzyme activity } \\
\hline Cystine arylamidase & - & - & + \\
\hline Naphthol-AS-BI-phosphohydrolase & + & + & $\mathrm{w}$ \\
\hline$\alpha$-Galactosidase & - & - & + \\
\hline$\beta$-Galactosidase (2-naphthyl- $\beta$-D-galactopyranoside) & - & - & + \\
\hline DNA G $+\mathrm{C}$ content $(\mathrm{mol} \%)$ & 39.6 & 41.9 & $44.5^{*}$ \\
\hline
\end{tabular}

${ }^{\star}$ Data from Nedashkovskaya et al. (2003).

and/or iso- $\mathrm{C}_{15: 0}$ 2-OH). The DNA $\mathrm{G}+\mathrm{C}$ content is approximately $39.6-44.5 \mathrm{~mol} \%$. As determined by $16 \mathrm{~S}$ rRNA gene sequence analysis, the genus Reichenbachiella is a member of the family Cytophagaceae, phylum Bacteroidetes.

\section{Emended description of Reichenbachiella agariperforans Nedashkovskaya et al. 2005}

The description is as given by Nedashkovskaya et al. (2003, 2005) with the following modifications and additions.
Utilizes D-glucose, D-mannose, D-mannitol, $N$-acetylglucosamine, maltose, gluconate, sucrose, adipate, malate, acetate, L-serine, L-histidine and 2-ketogluconate; does not utilize L-arabinose, caprate, citrate, phenylacetate, Lrhamnose, D-ribose, inositol, itaconate, suberate, malonate, lactate, L-alanine, 5-ketogluconate, glycogen, salicin, melibiose, L-fucose, D-sorbitol, propionate, valerate, 3-hydroxybutyrate, 3-hydroxybenzoate, 4-hydroxybenzoate or L-proline (API 32GN and API 20NE galleries). Carotenoid and flexirubin-type pigments are produced. 
Table 2. Cellular fatty acid compositions of strains PCP $11^{\top}$ and PCP104 and R. agariperforans KCTC $12369^{\top}$

Strains: 1 , strain PCP11 ${ }^{\mathrm{T}} ; 2$, strain PCP104; 3, R. agariperforans KCTC $12369^{\mathrm{T}}$. All data are from this study. Values are percentages of total fatty acids; fatty acids that amounted to $<1 \%$ of the total fatty acids in all strains are not shown. tr, Trace ( $<1 \%$ of the total); - , not detected; ECL, equivalent chain-length.

\begin{tabular}{|c|c|c|c|}
\hline Fatty acid & 1 & 2 & 3 \\
\hline \multicolumn{4}{|l|}{ Saturated } \\
\hline $\mathrm{C}_{12: 0}$ & 1.2 & 1.3 & $\operatorname{tr}$ \\
\hline $\mathrm{C}_{13: 0}$ & 1.1 & $\operatorname{tr}$ & $\operatorname{tr}$ \\
\hline $\mathrm{C}_{14: 0}$ & 2.3 & 3.2 & 1.8 \\
\hline $\mathrm{C}_{15: 0}$ & 11.4 & 5.0 & - \\
\hline $\mathrm{C}_{16: 0}$ & 2.6 & 5.8 & 4.0 \\
\hline $\mathrm{C}_{18: 0}$ & 1.6 & 4.9 & 2.0 \\
\hline \multicolumn{4}{|l|}{ Unsaturated } \\
\hline $\mathrm{C}_{15: 1} \omega 6 c$ & 2.1 & 1.9 & $\operatorname{tr}$ \\
\hline $\mathrm{C}_{16: 1} \omega 5 c$ & 5.3 & 7.4 & 23.4 \\
\hline \multicolumn{4}{|l|}{ Branched chain } \\
\hline iso- $\mathrm{C}_{14: 0}$ & 2.2 & 3.0 & $\operatorname{tr}$ \\
\hline iso- $\mathrm{C}_{15: 0}$ & 21.9 & 20.6 & 19.7 \\
\hline iso- $\mathrm{C}_{15: 1} \mathrm{~F}$ & 6.8 & 5.3 & - \\
\hline iso- $\mathrm{C}_{16: 0}$ & 2.9 & 4.6 & $\operatorname{tr}$ \\
\hline iso- $\mathrm{C}_{16: 0} 3-\mathrm{OH}$ & 1.5 & 2.6 & $\operatorname{tr}$ \\
\hline iso- $\mathrm{C}_{17: 0} 3-\mathrm{OH}$ & 1.2 & 1.4 & 1.9 \\
\hline \multicolumn{4}{|l|}{ Hydroxy } \\
\hline $\mathrm{C}_{15: 0} 2-\mathrm{OH}$ & 3.0 & 1.7 & $\operatorname{tr}$ \\
\hline $\mathrm{C}_{16: 0} 2-\mathrm{OH}$ & $\operatorname{tr}$ & 1.5 & 1.6 \\
\hline Summed feature $4^{*}$ & 17.3 & 14.3 & 22.8 \\
\hline Unknown ECL 14.97 & 8.3 & 4.5 & 12.0 \\
\hline
\end{tabular}

* Summed features represent groups of two or three fatty acids that could not be separated by GLC with the MIDI system. Summed feature 4 comprised iso- $\mathrm{C}_{15: 0} 2-\mathrm{OH}$ and/or $\mathrm{C}_{16: 1} \omega 7 c$.

\section{Description of Reichenbachiella faecimaris sp. nov.}

Reichenbachiella faecimaris (fae'ci.ma'ris. L. n. faex, faecis sediment; L. n. mare, -is the sea; N.L. gen. n. faecimaris of the sediment of the sea).

Cells are Gram-staining-negative, strictly aerobic, oxidaseand catalase-positive, straight rods, approx. $0.3-0.5 \mu \mathrm{m}$ in diameter and $3.0-5.0 \mu \mathrm{m}$ long, motile by gliding. Endospores are not formed. Colonies are beige and circular with regular edges, approx. $1.0-2.0 \mathrm{~mm}$ in diameter after 3 days of incubation at $28{ }^{\circ} \mathrm{C}$ on MA. Colonies are not sunken into the agar. Growth occurs at $5-35{ }^{\circ} \mathrm{C}$ (optimum, $28-30{ }^{\circ} \mathrm{C}$ ) and at $\mathrm{pH} 5.5-8.5$ (optimum, $\mathrm{pH} 7.0-7.5$ ). Requires sodium ions for growth; grows in the presence of $1-5 \%(\mathrm{w} / \mathrm{v}) \mathrm{NaCl}$ (optimum, 3\%). Carotenoid and flexirubin-type pigments are not produced. Casein, starch (soluble) and aesculin are hydrolysed, but gelatin, urea, alginate, DNA, Tweens 20, 40, 60 and 80, CM-cellulose, filter paper, starch (from rice), chitin and agar are not. Nitrate is not reduced, indole and $\mathrm{H}_{2} \mathrm{~S}$ are not produced and D-glucose is not fermented. Utilizes D-glucose, $\mathrm{N}$ acetylglucosamine, maltose, adipic acid, phenylacetic acid, sucrose, maltose, sodium acetate, L-alanine, glycogen, L-serine, L-histidine, potassium 2-ketogluconate and L-proline; does not utilize potassium gluconate, caprate, L-arabinose, D-mannose, citrate, L-rhamnose, inositol, itaconate, suberate, malonate, potassium 5-ketogluconate, salicin, melibiose, L-fucose, D-sorbitol, propionate, valerate, 3-hydroxybutyrate or 4-hydroxybenzonate (API 32GN and API 20NE galleries). Malate, D-ribose, lactate and 3hydroxybenzoate are weakly utilized. Acid is produced from D-galactose, D-glucose, $\mathrm{N}$-acetylglucosamine, amygdalin, aesculin ferric citrate, cellobiose, maltose, trehalose, glycogen, gentiobiose and potassium 2-ketogluconate. Production of acid from sucrose and inulin is straindependent. Acid is not produced from the other substrates in the API $50 \mathrm{CH}$ gallery. Alkaline phosphatase, $\beta$ galactosidase (4-nitrophenyl $\beta$-D-galactopyranoside), esterase $(\mathrm{C} 4)$, esterase lipase $(\mathrm{C} 8)$, leucine arylamidase, valine arylamidase, acid phosphatase, naphthol-AS-BI-phosphohydrolase, $\alpha$-glucosidase (weak) and $N$-acetyl- $\beta$-glucosaminidase activities are present; arginine dihydrolase, urease, lipase (C14), cystine arylamidase, trypsin, $\alpha$ chymotrypsin, $\alpha$-galactosidase, $\beta$-galactosidase (2-naphthyl $\beta$-D-galactopyranoside), $\beta$-glucuronidase, $\beta$-glucosidase (6bromo-2-naphthyl $\beta$-D-glucopyranoside), $\alpha$-mannosidase and $\alpha$-fucosidase activities are absent (API 20NE and API ZYM galleries). Susceptible to ( $\mu$ g per disc) ampicillin (10), chloramphenicol (25), erythromycin (15), mitomycin C (50), streptomycin (10) and tetracycline (30), but resistant to gentamicin (10), kanamycin (30) and penicillin G (10). The major respiratory quinone is MK-7. The major cellular fatty acids are iso- $\mathrm{C}_{15: 0}$, summed feature $4\left(\mathrm{C}_{16: 1} \omega 7 c\right.$ and/ or iso- $\left.\mathrm{C}_{15: 0} 2-\mathrm{OH}\right)$ and $\mathrm{C}_{15: 0}$. The DNA $\mathrm{G}+\mathrm{C}$ content is $39.6-41.9 \mathrm{~mol} \%$ (HPLC).

The type strain is $\mathrm{PCP} 11^{\mathrm{T}}\left(=\mathrm{KACC} 14523^{\mathrm{T}}=\mathrm{JCM}\right.$ $\left.16588^{\mathrm{T}}\right)$, isolated from a tidal flat of the Yellow Sea, Korea.

\section{Acknowledgements}

This work was supported by a grant of the Korean Ministry of Education, Science and Technology (the Regional Core Research Program/Chungbuk BIT Research-Oriented University Consortium). We thank Dr Olga Nedashkovskaya for helpful discussions about the pigment production of the isolated strains.

\section{References}

Agarwal, S., Hunnicutt, D. W. \& McBride, M. J. (1997). Cloning and characterization of the Flavobacterium johnsoniae (Cytophaga johnsonae) gliding motility gene, gldA. Proc Natl Acad Sci U S A 94, 1213912144 .

Bernardet, J.-F., Nakagawa, Y. \& Holmes, B. (2002). Proposed minimal standards for describing new taxa of the family Flavobacteriaceae and emended description of the family. Int J Syst Evol Microbiol 52, 1049-1070.

Chun, J., Lee, J. H., Jung, Y., Kim, M., Kim, S., Kim, B. K. \& Lim, Y. W. (2007). EzTaxon: a web-based tool for the identification of 
prokaryotes based on $16 \mathrm{~S}$ ribosomal RNA gene sequences. Int J Syst Evol Microbiol 57, 2259-2261.

Euzéby, J. P. (1997). List of bacterial names with standing in nomenclature: a folder available on the Internet. Int J Syst Bacteriol 47, 590-592. http://www.bacterio.cict.fr

Fitch, W. M. (1971). Toward defining the course of evolution: minimum change for a specific tree topology. Syst Zool 20, 406-416.

González, J. M., Mayer, F., Moran, M. A., Hodson, R. E. \& Whitman, W. B. (1997). Microbulbifer hydrolyticus gen. nov., sp. nov., and Marinobacterium georgiense gen. nov., sp. nov., two marine bacteria from a lignin-rich pulp mill waste enrichment community. Int J Syst Bacteriol 47, 369-376.

Hall, T. A. (1999). BioEdit: a user-friendly biological sequence alignment editor and analysis program for Windows 95/98/NT. Nucleic Acids Symp Ser 41, 95-98.

Hiraishi, A., Ueda, Y., Ishihara, J. \& Mori, T. (1996). Comparative lipoquinone analysis of influent sewage and activated sludge by highperformance liquid chromatography and photodiode array detection. J Gen Appl Microbiol 42, 457-469.

Kimura, M. (1983). The Neutral Theory of Molecular Evolution. Cambridge: Cambridge University.

Ludwig, W., Euzéby, J. \& Whitman, W. B. (2008). Draft taxonomic outline of the Bacteroidetes, Planctomycetes, Chlamydiae, Spirochaetes, Fibrobacteres, Fusobacteria, Acidobacteria, Verrucomicrobia, Dictyoglomi, and Gemmatimonadetes. http://www.bergeys.org/outlines/Bergeys_Vol_ 4_Outline.pdf

Mesbah, M., Premachandran, U. \& Whitman, W. B. (1989). Precise measurement of the $\mathrm{G}+\mathrm{C}$ content of deoxyribonucleic acid by highperformance liquid chromatography. Int J Syst Bacteriol 39, 159-167.

Nedashkovskaya, O. I., Suzuki, M., Vysotskii, M. V. \& Mikhailov, V. V. (2003). Reichenbachia agariperforans gen. nov., sp. nov., a novel marine bacterium in the phylum Cytophaga-Flavobacterium-Bacteroides. Int $\mathrm{J}$ Syst Evol Microbiol 53, 81-85.
Nedashkovskaya, O. I., Kim, S. B., Suzuki, M., Shevchenko, L. S., Lee, M. S., Lee, K. H., Park, M. S., Frolova, G. M., Oh, H. W. \& other authors (2005). Pontibacter actiniarum gen. nov., sp. nov., a novel member of the phylum 'Bacteroidetes', and proposal of Reichenbachiella gen. nov. as a replacement for the illegitimate prokaryotic generic name Reichenbachia Nedashkovskaya et al. 2003. Int J Syst Evol Microbiol 55, 2583-2588.

Park, S. J., Kang, C. H. \& Rhee, S. K. (2006). Characterization of the microbial diversity in a Korean solar saltern by $16 \mathrm{~S}$ rRNA gene analysis. J Microbiol Biotechnol 16, 1640-1645.

Reichenbach, H. (1989). The order Cytophagales Leadbetter 1974, 99 ${ }^{\mathrm{AL}}$. In Bergey's Manual of Systematic Bacteriology, vol. 3, pp. 20112073. Edited by J. T. Staley, M. P. Bryant, N. Pfennig \& J. C. Holt. Baltimore: Williams \& Wilkins.

Saitou, N. \& Nei, M. (1987). The neighbor-joining method: a new method for reconstructing phylogenetic trees. Mol Biol Evol 4, 406-425.

Sasser, M. (1990). Identification of bacteria by gas chromatography of cellular fatty acids, MIDI Technical Note 101. Newark, DE: MIDI Inc.

Smibert, R. M. \& Krieg, N. R. (1994). Phenotypic characterization. In Methods for General and Molecular Bacteriology, pp. 607-654. Edited by P. Gerhardt, R. G. E. Murray, W. A. Wood \& N. R. Krieg. Washington, DC: American Society for Microbiology.

Tamura, K., Dudley, J., Nei, M. \& Kumar, S. (2007). MEGA4: molecular evolutionary genetics analysis (MEGA) software version 4.0. Mol Biol Evol 24, 1596-1599.

Thompson, J. D., Gibson, T. J., Plewniak, F., Jeanmougin, F. \& Higgins, D. G. (1997). The CLUSTAL_X windows interface: flexible strategies for multiple sequence alignment aided by quality analysis tools. Nucleic Acids Res 25, 4876-4882.

Weisburg, W. G., Barns, S. M., Pelletier, D. A. \& Lane, D. J. (1991). 16 S ribosomal DNA amplification for phylogenetic study. J Bacteriol 173, 697-703. 